\title{
19. 持続可能な産業社会変革のための土木建設システムの環境負荷評価

\author{
EVALUATION OF ENIVIRONMENTAL IMPCAT IN CIVIL INFRASTRUCTURE SYSTEMS WITH \\ RESPECT TO SUSTAINABLE INDUSTRIAL TRANSFORMATION
}

盛岡 通*、○吉田 登* Tohru MORIOKA, Noboru YOSHIDA

\begin{abstract}
This paper aims to evaluate environmental impacts from resource dissipation to global warming in civil infrastructure systems as an basis of discussion on sustainable industrial transformation for this industrial society. Civil infrastructure system give considerable impacts both directly and indirectly through various product chains and supply of related societal services. From this aspects, first, the content of environmental impacts were divided into several categories according to its repercussive characteristics: Second, specific environmental impacts were analyzed using life cycle inventory approaches including input-output analysis. As a result, the followings were examined : 1) various product chains were observed with relation to release of carbon dioxide and industrial waste, and steel consumption due to construction activities; 2) machinery and utility - derived impacts were recognized to some extent as well as cumulative stock impacts of the infrastructure bodies; 3) considerable environmental impacts due to societal services supported by civil infrastructure indicated the necessity of further discussion on the allocation of responsibility for reducing the impacts.
\end{abstract}

KEYWORDS; Civil Infrastructure Systems, Industrial Transformation, Eco-Restructuring, Life Cycle Assessment, Product-Chain Analysis

\section{1. 研究の背景と目的}

日本の炭酸ガス排出量の 4 割近く 1)をになう土木建築活動において、C O P 3 以降、その環境効 率（Eco-Efficiency）を飛躍的に向上させるための具体的な方向性の議論が求められている。本研 究は、そのための基礎として、全国レベルでの土木建設システムの環境負荷の再評価をおこなっ たものである。

土木社会基盤の産業社会への影響は、単にその構造物ボリュームとそれに伴う施工時の環境負 荷の大きさにより規定されるだけでなく、建設資材の生産から供用に伴う社会サービスに至る幅 広い時空間の領域にわたるものである。その意味で、土木建設業の活動に伴う環境インパクトを 建設活動との直接、間接の関わりの程度や即時的、累積的などの負荷波及の特徽の違いに対応さ せて幾つかのカテゴリーに分類し、これに応じた環境負荷のパフォーマンスを分析することで、 産業社会への幅の広い環境インパクトに対応（Response）する議論に資する情報提供を目的とする。

*大阪大学工学研究科環境工学専攻 Dept. of Environmental Eng., Graduate Course of Engineering, Osaka University 


\section{2. 研究の方法}

産業連関表およびその付帯表、建設関連統計、建設副産物に関する統計等を用いて、工事の際 に直接排出される負荷（区分 1 ）、構造物の資材生産とその廃棄に伴って生じる負荷（区分 2 - a ， b ）、建設物や装置の供用に伴いそれらを通過するものやサービスの直接フローによる負 荷（区分 3 ）、この直接フローのライフサイクルの前後で排出される負荷（区分 4 ） という環境 負荷インパクトのカテゴリーごとに環境負荷を計量し、各カテゴリーごとの大きさの此較や影響 力の大きさを評価した。

まず第 1 に、土木建築活動全体について、1990 年の環境負荷を直接排出（区分 1 ）及び構造物

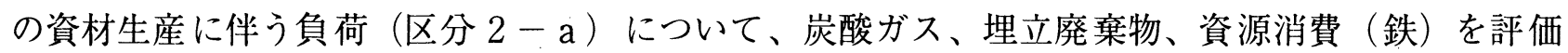
指標として計量をおこなった。方法論は著者らの既報に詳説するところの産業連関分析によるア プローチをとり、1990年建設部門分析用産業連関表（一般91 部門、建設68部門） ${ }^{2)}$ を用いて構造物 種類を詳細に検討した。環境負荷データについては、炭酸ガス及び資源消費（普通鋼）は物量表 デー夕、埋立廃棄物については、厚生省の産業廃棄物業種別廃棄物種別発生量デー夕を補完デー 夕で91一般部門分類に配分した鶴巻ら（1997） ${ }^{4)}$ の既往原単位データを用いた。第 2 に、都市活動 の器としての “建築物”を中心に、そこで展開される都市活動に必要な主要な資源である水につ いてその供給の上下流を支える構造物として“ダム”，“下水道”を取り上げ、さらにこれら物 質資源の輸送を支える構造物“道路（及び道路橋梁）”の各土木建設システムを対象として、環 境負荷インパクトのカテゴリーごとの寄与を炭酸ガスについて定量化した。各カテゴリー毎の計 量方法を表 -1 に示す。1990年の建設部門の国内生産額82兆円のうち、これら 4 種の構造物の生 産額の寄与は合計で約78\%に上り、またダム、下水道、道路は建設部門生産額全体の約 $37 \%$ 占 める土木構造物のうち、4割を担っている。

\section{表ー 1 環境負荷インパクトカテゴリー別の計青方法}

\begin{tabular}{|c|c|c|}
\hline 構造物 & 環境インパクトカテゴリー & 推計方法 \\
\hline 建築物 & $\begin{array}{l}\text { 区分 } 1: \text { 建築物建設時負荷 } \\
\text { 区分 } 2: \text { 建設資材製造時負荷 } \\
\text { 区分 } 3: \text { 運用時動力消費に伴う負荷 } \\
\text { 区分 } 4: \text { 設備機器、O·A機器製造 }\end{array}$ & $\begin{array}{l}\text { 建築統計年報の用途・構造別着工、滅失床面積データに } \\
\text { よりストックを集計。区分 } 1 ， 2 \text { は床面積当たりの負荷 } \\
\text { 原単位を乗じて算定。区分 } 3 \text { は、総合エネル゙ー統計よ } \\
\text { り集計。区分 } 4 \text { は、耐用年数設定して各種統計より算定。 }\end{array}$ \\
\hline ダム & \begin{tabular}{|l} 
区分 $1:$ ダム築造時負荷 \\
区分 $2 ：$ ダム建設資材製造時負荷 \\
区分 $3:$ 上水システム直接負荷 \\
区分 $4:$ 区分 3 に伴う間接負荷
\end{tabular} & $\begin{array}{l}\text { ダム年鑑による竣工年別ダム形式別データを集計。区分 } \\
1 \text { ，2 は堤体積データに堤体積当たりの環境負荷原単位 } \\
\text { を乗じて算定。区分 } 3 ， 4 \text { は、既往研究による上水シス } \\
\text { テム L C A の供給水量あたり原単位を積み上げて算定。 }\end{array}$ \\
\hline 道路 & \begin{tabular}{|l} 
区分 $1:$ 道路施工時負荷 \\
区分 $2 ：$ 舗装材等資材製造時負荷 \\
区分 $3:$ 自動車燃料消費直接負荷 \\
区分 $4:$ 自動車製造時負荷
\end{tabular} & $\begin{array}{l}\text { 道路統計年報による舗装材別車線別道路延長、構造別道 } \\
\text { 路橋梁延長、トンネル延長の各デー夕を集計。区分 } 1 \text {, } \\
2 \text { は単位環境負荷原単位を乗じて算定。区分 } 3 \text { は総合工 } \\
\text { ネルギー統計, 区分 } 4 \text { は保有台数にL C A 原単位利用。 }\end{array}$ \\
\hline 下水道 & \begin{tabular}{|l} 
区分 $1:$ 下水道建設時負荷 \\
区分 $2:$ 建設資材製造時負荷 \\
区分 $3:$ 運用時エネル ギー消費 \\
区分 $4:$ 薬剤、污泥処理等
\end{tabular} & $\begin{array}{l}\text { 下水道統計による処理開始年次別処理場データを集計。 } \\
\text { 区分 } 1 \text { ～} ４ \text { は計画最大処理量に対して単位処理量あたり } \\
\text { の環境負荷原単位を乗じて算定。 }\end{array}$ \\
\hline
\end{tabular}




\section{3.土木建設システムの環境負荷評価}

3.1 日本の年間土木建設活動に伴う構造物別の環境インパクト

日本の G N P に占める建設投資のシェアは、高度成長期以降、15.3\%（1960年）、20.8\%（1970 年）、18.9（1980年）、17.5\%（1990 年）と、今なお一般会計の 2 割近くを堅持してきている。こ の建設活動が建設資材の生産、輸送等を通して他の産業部門と広い関わりを持っていることは一 般に知られているが、環境負荷の排出や資源消費に対しても同様な物質一製品連鎖（Material Product - Chain） ${ }^{5)}$ 有している様相を、産業連関分析により定量的に把握することができる。

図ー1に、建設活動に必要な財・サービスの中間需要を通して、その川上でこれらの供給を担 うどの（直接排出者としての）他の産業部門にどの程度環境負荷排出や資源消費を委ねているか について炭酸ガス、埋立廃亲物、鉄資源消費（普通鋼）を対象に計量した結果を示す。

炭酸ガスの排出では、これらの合計量は、建設工事に伴う直接排出量 $3.5 \mathrm{M} \mathrm{t} C$ の約16倍に相当

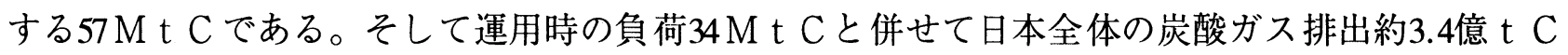
の 4 割近くを占める。部門別シェアをみると既往の製品 L C A 的アプローチによる研究成果と同 様、土石製品部門のシェアが大きく建設活動に起因する他の産業部門全体からの排出量の $35 \%$ に 相当する $29.8 \mathrm{M} \mathrm{t}$ C を排出している。電力部門（資材.や装置の製造動力の提供）、鉄鋼部門（資材 や装置・器具に使用される鉄の供給）、輸送部門（資材や装置・器具の輸送）は、いずれもセメ ント、土石部門の約半分程度の寄与であり、それぞれ $11.6 \mathrm{M} \mathrm{t} \mathrm{C}(20 \%) 、 9.6 \mathrm{M} \mathrm{t} \mathrm{C} \mathrm{(17 \% )、}$

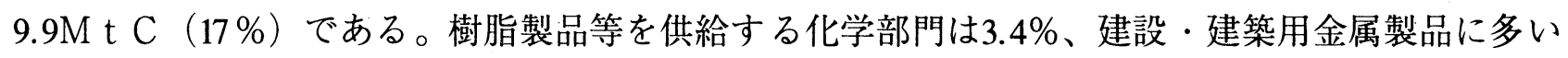
非鉄の製造部門での燃料消費は $1.7 \%$ であるポンプ等の装置を製造する機械部門での排出は $0.2 \%$. と少ないが、これは電力消費は電力部門からの排出として計上されていることによる。

埋立廃棄物では、土石製品部門のシェアが炭酸ガスに比して大きく上昇し、52\%を占める。続 いて鉄鋼部門が $10 \% 、$ 非鉄が $6 \%$ 占め、その他の部門の寄与は相対的に低い。

鉄資源消費では、構造物そのものへの現場施工での消費が67\%を占め、コンクリート既製品等 への組込みは3\%程度である。それ以外では、非鉄部門において建設・建築用金属製品の一部とし て消費される鉄が $28 \%$ と大きなシェアを占めており、分解容易性設計（Design for Disassembly） の配慮が重要となる。

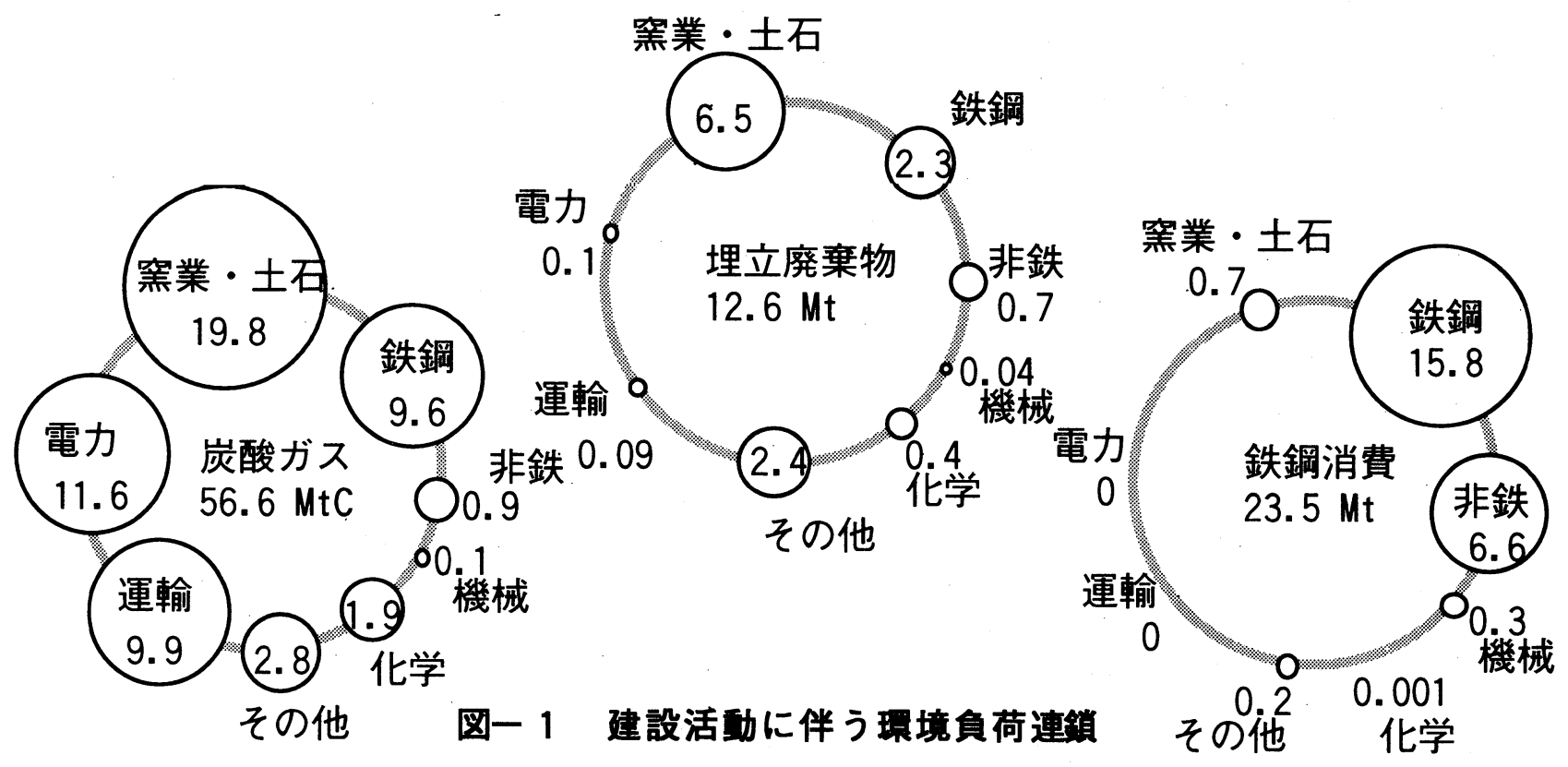


図一 2 は、各建設活動（構造物）ごとの製品連鎖を示したものである。構成比のオーダーは各 建設活動間で大きな差はない。素材系部門へのシェアが高いのは、砂防（67\%）、環境衛生 $(62$ $\%) 、$ 鉄道軌道 $(62 \%)$ 、道路橋梁 $(62 \%)$ であり、駆体部分のウエイトの高い構造物の特徴を 示している。機械系は、電力施設 $(0.4 \%)$ や事務所建築 $(0.3 \%)$ で高く、制御機器類の内包によ るものと考えられる。輸送部門へは、海岸事業（22\%）や空港（22\%）が高く、建設サイトと資 材生産地との距離との関連が類推される。

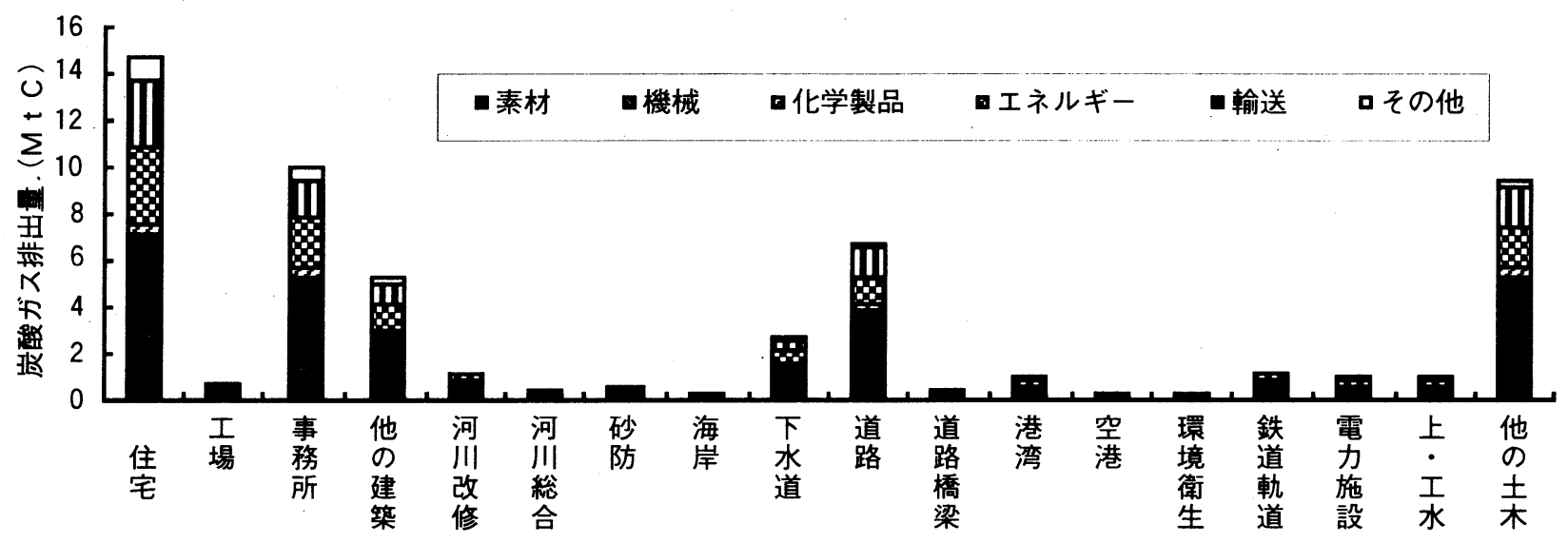

図一 2 各土木建設活动ことの環境負荷連鎖

\section{2 土木·建築構造物別の環境インパクト評価}

環境インパクトの各カテゴリーのウェイトの違いを代表する 4 種の構造物（建築物、ダム、道 路、下水道）を対象に、炭酸ガスについて計量した。現況の建設インフラが提供するサービス起 因のフローの環境インパクトを比較評価するため、可能な限り経年のストック全体を対象とした。 取り上げる環境インパクトのカテゴリーは、表－1（前掲）のとおりである。

\section{(1) 建築物}

駆体の器の上で、代謝スケールの異なる様々な財・サービスのフローが提供され、それが環境 負荷に繋がっているという建設インフラの特徵を象徵する構造物である。駆体そのものは数十年 という長期の更新スケールであるが故に新規着工のインパクトが大きいことはアジアの後発工業 国の特徴であるが、戦後かなりの速度で建築物の集積を行ってきた日本では、ストック更新のイ ンパクトも無視できないオーダーとなっている。また日常、都市業務活動に伴う紙等の生活消費 財のフローに加えて、特に膨大な流体（水）輸送に起因して、そのための機器動力の消費が日単 位のスケールでおこなわれ、かつそれを支えるポンプ等一般産業機械が構造物の数分の.1の代謝 期間で更新されている。

まず、最も更新スケールの長い、構造物本体について、建築統計年報の着工、滅失建築物の統 計をもとに推計したものを図ー 3 に示す。1952 年以降1990年迄の全国で着工された建築物床面積 は650億吕2に対してその約4分の1に相当する滅失床面積 $162 \mathrm{Mm} 2$ を除いた現存ストック $618 \mathrm{Mm} 2$ の建 設に伴う炭酸ガス排出量は616M t C となった（85年ベースの原単位を用いているので過小評価）。 着工分は、これを一割弱上回る651M t C となった。また、滅失に伴い系外に排出された資源量は 1976年以降、概ね 1000 万 $\mathrm{t}$ に達する水準で推移しており、1990年の滅失による資源排出量推計 1136 万 $\mathrm{t} \cdot$ は、日本全国の建設廃棄物発生量7590万 $\mathrm{t}$ の $15 \%$ に相当する。中でも重量比の最も大き い砂利資源量は $1694 \mathrm{M} \mathrm{t}$ に上る。

また、図ー4に示すように、この建築物ストックの上で展開される民生サービスに伴う年間の 


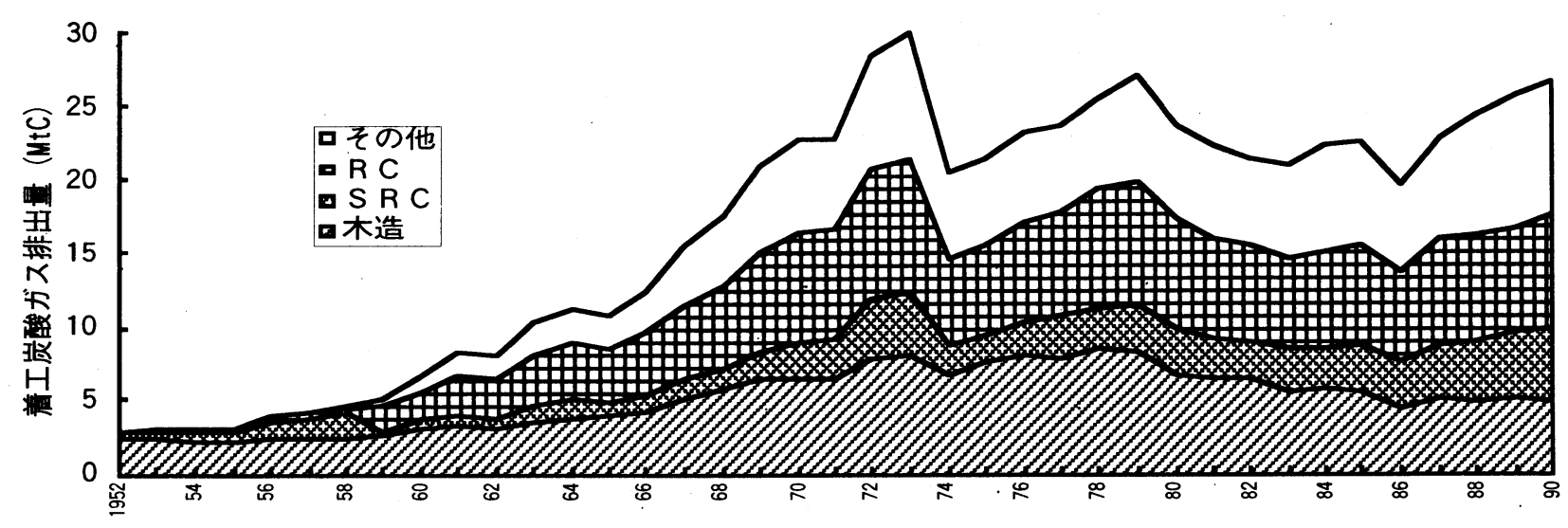

図一３前工建策物に伴う炭酸ガス排出吾の释時变化

年間の

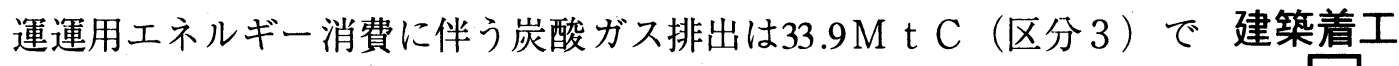

あるが、送風機やポンプなど流体制御に用いられる動力消費が無視で きない。水を例にとれば、年間の業務商業系の床面積あたり水使用量

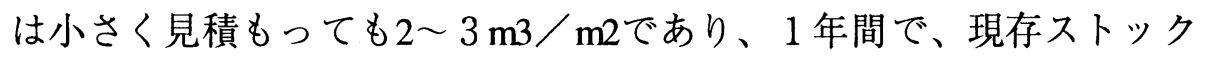
資源量の 2 倍の水フローが都心業務構造物を通過する勘定となる。

\section{(2) ダム}

ダムも建築物同様、古くから社会インフラとして蓄積のされており、 その累積効果は大きい。1995年度までに竣工したグム3171のうち、堤 体積が判明、もしくは有効貯水量から推計》)できたダム3128にいて、 既往研究 (小泉・高柳，1996） ${ }^{8}$ )による堤体積あたり炭酸ガス排出量

(フィルタイプ15.37 t C m m, コンクリートタイプ114.73 t C m m) を

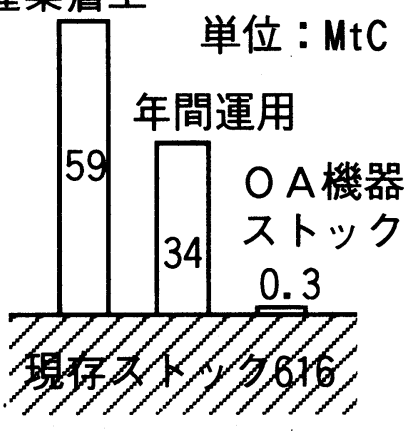

图一 4 建策物ストッ ク上でのサービスに起 因する環填負荷

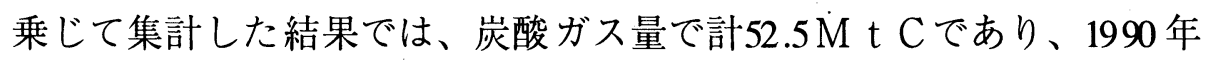
の建設活動起因の炭酸ガス排出量（運用時を除く）に匹敵する。ダムは、建設時の直接排出（区

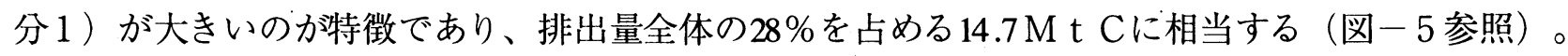

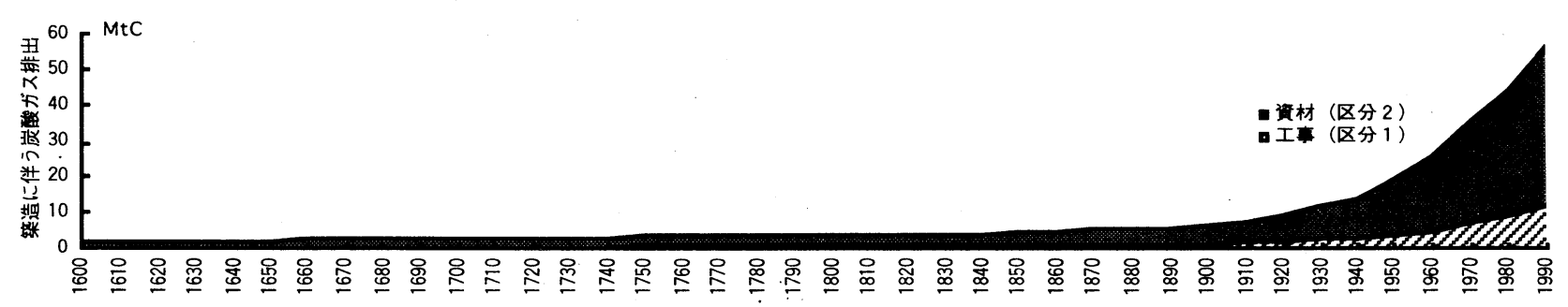

\section{图一 5 ダム策造に伴う炭酸ガス排出田の経年変化（累䖽）}

このような炭酸ガス排出の他にも自然地の改変など建設時の 大きな環境インパクトをもたらしてきた反面、自然流下による 都市活動水の供給が、取水動力消費など水利用のフローに伴う 環境インパクトを低減させてきた。図ー6に示すとおり、ダム 構造物の器を通じて供給される上水供給量約7.59 Mm3（1990年） 9)に対する水源から導水、浄水、送水、配水での運用動力及びケー キ焼却（区分 3 ）に起因する炭酸ガス排出 ${ }^{(0)}$ は252579 t Cであ り、それをささえる装置機器や薬剤の生産で生じる年あたりの
単位: MtC

運用に伴う

年間運用 年間間接排出

（動力等）（装置、薬剂等）

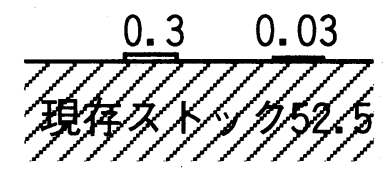

図一 6 上水供給サービス

に伴う炭酸ガス排出 
炭酸ガス排出量 ${ }^{11}$ （区分 4）は区分 3 のフローに伴う值接負荷の約 1 割の $28682 \mathrm{t}$ C となる。

(3) 道路

道路は、構造物自体の更新 (補修) が比較的短い周期でおこなわれることが特徵であり、その 器の上で提供される輸送サービスに起因する直接負荷が大きい性格を有する構造物である。道路 構造は言うまでもなく、I T S による制御や自動車の地域社会での保有など社会システムを含め たインフラ整備側の要件が、サービスの媒体である車利用や環境負荷と密接な関連を持つにも関 わらず、炭酸ガスをはじめとするこれら環境負荷排出抑制への対応 (Response) に対する関連需要 主体間での議論は十分でない。本解析でも、これについての態度は明示していない。

道路ストックの状況は、道路統計年報に整理されて いるが、環境インパクトに大きく関連する舗装材料別 の道路延長のデー夕を経年で得ることができないため、 ここでは集計ストック值をもとに計算をおこなった。 道路橋梁及び道路トンネルについても同様である。原 単位は、既往文献 ${ }^{12)}{ }^{13)}$ をとに、単位舖装面積、単位 橋梁面積、単位トンネル容積あたり炭酸ガス排出量の 原単位を適用した。

図一7に示すとおり、構造物ストックに対する年䦓 自動車利用の環境負荷が 9 割（燃料消費 6 割、自動車 製造 3 割）に達するなど、サービスに俳うフローが毞 越している。

（4）下水道

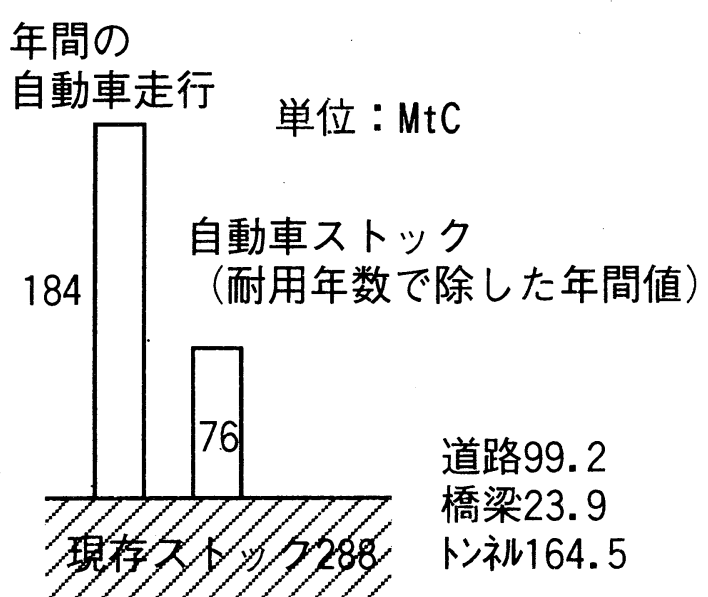

図一 7 道路群設と自動車走行に伴 う炭酸ガス排出

下水道は、土木建設システムの中で、構造物自体の建設、資材消費に伴う負荷（区分 $1 ， 2$ ） に比較して供用洔の動力や薬品の消費などフローに伴う環境インパクト（区分 $3 ， 4 ）$ が卓越す る構造物として位置づけられる。

下水道統計をもとに、処理開始年別の処理規模別下水終末処理場デー夕に処理容量（計画日最 大処理量）あたりの炭酸ガス排出量原単位データ ${ }^{14)}$ を乘じて、計量した結果を図ー- 8 に示す。

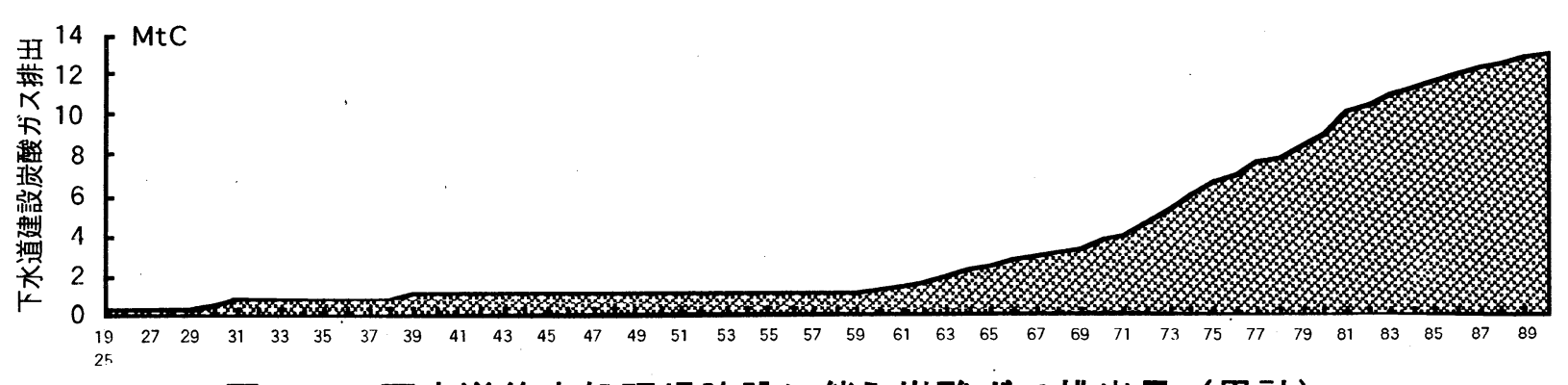

國一8 下水道終末処理場建設に伴う炭酸ガス排出至（累計）

全国ベースで、70 年代の処理埸建設に伴う炭酸ガス排出の伸びが認められる。90 年までに処 理を開始した処理場ストック形成に伴い排出された炭酸ガスの総量は、12.9 M t Cに上る。

さらに、下水処理に伴う運用時負荷を処理場ストック形成と比較して図ー 9 に示す。建築物と 同様、運用時動力消費起因の炭酸ガス排出が現存ストック建設時負荷の約 20 分の 1 程度のオー ダーでおこなわれている。ここでは推計の対象外としているが、污泥最終処分量は、陸上埋立で 93 万 $\mathrm{t}$ ，海面埋立で46万 $\mathrm{t}$. (いずれも1990年值) あり、この廃卒物輸送に伴うインパクトを含め ると、サービスに伴う間接的な環境インパクト（区分 4 ）は、より増大する。 


\section{4.まとめ}

本研究では、C O P 3 以降の持続可能な土木建設システムへの変 革を考える基礎として、土木建設活動およびそれらが提供する社会 サービスに伴う環境インパクトを類型化して計量をおこなった。

（1）素材系を中心とする土木建設システムの環境負荷の産業連鎖 を計量した。鉄資源消費では、建設金属部品での非鉄と鉄の混成部 材量が大きいことから、建設部品においても再資源化容易な設計が 重要であることが示唆される。

（2）建築物では構造物ストックの 20 分の 1 が運用負荷に相当す るなど、サービスに伴う運用時の負荷が大きい。そのかなりの部分 を流体輸送・制御が占めており、年間の都心地区水消費量がストッ ク資源量の 2 倍に上ることからもその制御に必要な機器の環境保全

年間の 処理施設運用

電力0.53

(水処理0.27

污泥 0.1

場内 P 0.09

その他0.07)

然料 0.05

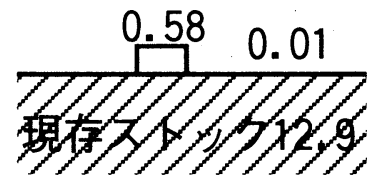

図一 9 下水优理軥ストッ クと運用時負荷 性が重要であることが認識される。

（3）ダムは、運用時サービスに伴う給水負荷を軽減する反面、建設時の負荷が卓越する構造物 であり、経時変化ではコンクリートダムの増加による資材起因の炭酸ガス排出が増加している様 子が認められ、リサイクル材など資材利用の環境配慮が今後も重要である。

（4）道路は自動車走行による炭酸ガスがストック形成負荷の 9 割に匹敵するなど、構造物の上 で提供されるサービスに伴う負荷の最も大きいインフラの典型であり、自動車の設計と連動した 環境保全型の道路設計が求められる。

（5）下水道は、構造物そのものの機能維持に必要な負荷が大きいインフラの典型であり、その ストック形成に対する運用時負荷の大きさは、建設物の比率に相当するほどである。中でも場内 ポンプや水処理ブロアなどの流体制御の動力が大きい。河川取水による上水システムでも同様で あり、土木建設システム全体での流体制御に伴う負荷の定量化や低減方策の検討が課題である。

\section{参考文献}

1) 酒井寛二・漆崎昇・中原智哉：建設資材製造時の二酸化炭素排出量経時変化と土木分野への影響，環境システム研究， Vol.25, pp.525-532

2)平成2年（1990年）建設部門分析用産業連関表，1995

${ }^{3)}$ 平成 2 年（1990年）産業連関表一計数編（2），1994

4) 鶴巻峰夫・野池達也：LＣＡに打ける多項目環境負荷量の定量化に関する研究, 環境ジステム研究, Vol.25, pp.217-227, 1997

5) Pier Vellinga et. al. : Industrial Transformation - An Inventory of Research, IHDP-IT no.8, pp. 1-87, 1997

6) ダム年鑑，（財）ダム協会，1997のダム建設状況総括表によると、近世・汇戸洔代（1600-1900）のダム築造数は552 であり、1995年迄の竣上ダム数3171の17\%に相当

7) ダム年鑑，（財）ダム協会, 1997の「第 6. 編帳表別解説・付録」による河川総合開発事業竣工ダム堤体積一有効貯水 容量相関図」より対数回帰式を作成して推計した

8) 小泉泰通・高柳則男：ダム建設のライフサイクル評価，第 4 回地球環境シンポジウム講演集, pp.49-56, 1996

9) 水道統計年報（1994）より、1990年の上水供給量 $15822020 \mathrm{~m} 3$ に計画 1 日最大取水量ベースのダム水源比率 0.48 を乗 じて推計

10)（社）資源協会編：家庭生活のライフサイクルエネルギーより、ダム以外の水源〜配水ま.での積み上げデー夕を物量 単位で抽出して推計

11) 前揭 9 ) により同様に推計

12)盛岡通：土木建設システムにおけるL C A の考え方と事例，第 4 回地球環境シンポジウム講演集，pp.29-34

${ }^{13)}$ 土木学会環境負荷評価（LCA）検討小委員会：土木建設業における環境負荷評価（LC A ) 検討部会 平成 7 年度 および平成 8 年度報告に挍ける道路舗装（船水、真下）、トンネル（児玉、高野）、橋梁上部工（金）の各W G 報告デー 夕による

14) 鶴巻峰夫・藤岡荘介・内藤弘：下水終末処理施設のライフサイクルでの環境負荷の定量化について, 第 4 回地球環境 シンポジウム講演集, pp.57-62, 1996 